\title{
Ni Microspheres as Electrocatalysts for Ethanol Oxidation in an Alkaline Medium
}

\author{
A. Altamirano-Gutiérrez, G.E. Martínez-Tapia, L.C. Ordóñez ${ }^{*}$ \\ Unidad de Energía Renovable, Centro de Investigación Científica de Yucatán A. C., Parque Científico \\ Tecnológico de Yucatán, Carretera Sierra Papacal-Chuburna Puerto Km 5, Sierra Pacacal, Yucatán, \\ México. C. P. 97302. Tel.: +52 (999) 9300760, Ext. 1205. \\ "E-mail: $\underline{\text { lcol@ cicy.mx }}$
}

doi: $10.20964 / 2018.05 .04$

Received: 30 November 2017 / Accepted: 29 January 2018 / Published: 10 April 2018

We report the synthesis of nickel microspheres and their structural and electrochemical characterization. The materials were prepared by the microemulsion technique from $\mathrm{NiSO}_{4} \cdot 6 \mathrm{H}_{2} \mathrm{O}$ and $\mathrm{NaOH}$, and using $\mathrm{NaH}_{2} \mathrm{PO}_{2} \cdot \mathrm{H}_{2} \mathrm{O}$ as a reducing agent. Sodium dodecyl sulfate (SDS) was used as a surfactant. The following ternary formulations were used for their synthesis: $\mathrm{N} 1\left(90 \% \mathrm{H}_{2} \mathrm{O}-7.5 \% \mathrm{SDS}\right.$ $2.5 \%$ Pentanol), $\mathrm{N} 2\left(92.5 \% \mathrm{H}_{2} \mathrm{O}-5 \%\right.$ SDS-2.5\%Pentanol $), \mathrm{N} 3\left(95 \% \mathrm{H}_{2} \mathrm{O}-3.75 \% \mathrm{SDS}-1.25 \%\right.$ Pentanol $)$ and $\mathrm{N} 4\left(99 \% \mathrm{H}_{2} \mathrm{O}-0.75 \%\right.$ SDS- $0.25 \%$ Pentanol). The catalysts were characterized by scanning electron microscopy (SEM) and X-ray diffraction (XRD). The catalytic activity for ethanol oxidation in an alkaline medium was evaluated by cyclic voltammetry (CV) and electrochemical impedance spectroscopy (EIS). The average diameters of the nickel microspheres ranged from 0.375 to $1.476 \mu \mathrm{m}$. On subjecting the materials to heat treatment in a nitrogen atmosphere at $300{ }^{\circ} \mathrm{C}$ for $4 \mathrm{~h}$, mixtures of polycrystalline $\mathrm{Ni}$ and nickel phosphide $\left(\mathrm{Ni}_{3} \mathrm{P}\right)$ were obtained. The best performance for the ethanol oxidation reaction (EOR) in an alkaline medium was recorded with non-heat-treated nickel microspheres, presenting a maximum peak potential at approximately $0.7 \mathrm{~V}$ vs. $\mathrm{Hg} / \mathrm{HgO}$ with normalized currents between 10.774 and $\left.18.198 \mathrm{~mA}_{(\mathrm{mgcat}}\right)^{-1}$. These results indicate that nickel microspheres are potential candidates for use as anodes in alkaline direct alcohol fuel cells (ADAFCs).

Keywords: Nickel microspheres, microemulsion synthesis, electrocatalysts, anode, alkaline direct alcohol fuel cells.

\section{FULL TEXT}

(C) 2018 The Authors. Published by ESG (www.electrochemsci.org). This article is an open access article distributed under the terms and conditions of the Creative Commons Attribution license (http://creativecommons.org/licenses/by/4.0/). 